\title{
Algılanan Sosyal Mübadele, İşe Yabancılaşma ve Sanal Kaytarma Davranışlarını Etkiler Mi? Mübadele İdeolojisinin Düzenleyici Rolü
}

\section{Şeyda Nur SEÇKİN ${ }^{1}$}

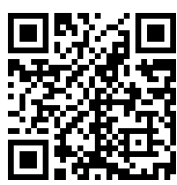

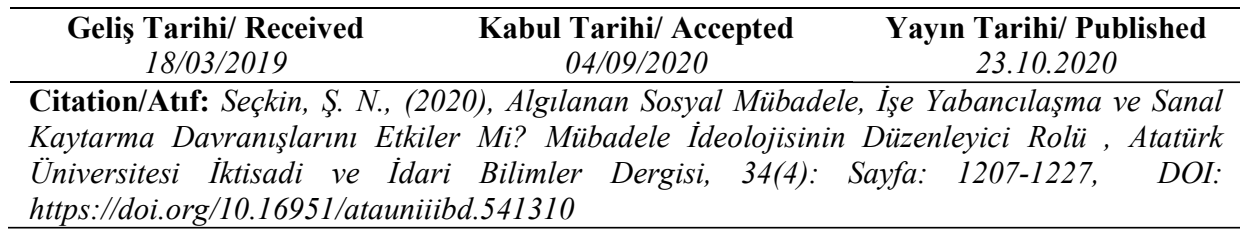

Öz: İnternet teknolojisindeki gelişmeler ve mobil iletişim araçlarının yaygınlaşmasıyla birlikte, internetin mesai saatleri içerisinde kişisel amaçlar için kullanımı artmış; sanal kaytarma örgüt yönetimi tarafından dikkate alınması gereken önemli bir konu haline gelmiştir. Bu çalışmada, algılanan sosyal mübadele ve işe yabancılaşmanın sanal kaytarma davranışları üzerindeki etkisi incelenmiş; mübadele ideolojisinin (exchange ideology) sosyal mübadele algısı-sanal kaytarma ve sosyal mübadele algısı-işe yabancılaşma ilişkisinde düzenleyici bir rol oynayıp oynamadığ 1 test edilmiştir. Araştırma sonuçları, algılanan sosyal mübadelenin sanal kaytarmayı negatif; işe yabancılaşmanın ise pozitif yönde etkilediğini göstermiştir. Ayrıca, işe yabancılaşmanın algılanan sosyal mübadele ve sanal kaytarma ilişkisinde aracılık etkisine sahip olduğu; mübadele ideolojisinin de algılanan sosyal mübadele-işe yabancılaşma ilişkisinde düzenleyici bir rol oynadığ 1 tespit edilmiştir.

Anahtar Kelimeler: Algılanan Sosyal Mübadele, İşe Yabancılaşma, Sanal Kaytarma, Mübadele İdeolojisi

Does Perceived Social Exchange Affect Work Alienation and Cyberloafing? The Moderating Role of Exchange Ideology

Abstract: With developments in internet technologies and mobile communication devices becoming widespread, the use of internet for personal purposes within working hours has increased and cyber loafing has become a major concern to organizations. This study aims to explore the effect of perceived social exchange and work alienation on cyber loafing and examine whether exchange ideology moderates the relationship of perceived social exchange with work alienation and cyber loafing. Study findings demonstrated that perceived social exchange has a negative; work alienation has a positive effect on cyber loafing. In addition, it was found that the relationship between perceived social exchange and cyber loafing was mediated by work alienation and the moderating effect of exchange ideology on perceived social exchange-work alienation relationship was significant.

Keywords: Perceived Social Exchange, Work Alienation, Cyberloafing, Exchange Ideology

${ }^{I}$ Dr. Öğr. Üyesi, İnönü Üniversitesi, İktisadi ve İdari Bilimler Fakültesi, İsletme Bölümü, Yönetim ve Organizasyon, https://orcid.org/0000-0002-2313-1340 
Algılanan Sosyal Mübadele, İşe Yabancılaşma ve Sanal Kaytarma Davranışlarını Etkiler Mi? Mübadele İdeolojisinin Düzenleyici Rolü

\section{EXTENDED SUMMARY}

\section{Research Problem:}

In this study, it was aimed to investigate whether workplace incivility has a positive effect on employees' withdrawal behaviors via emotional exhaustion. In addition, adopting Conservation of Resources Theory (Hobfoll, 2001) and based on previous study findings, it was hypothesized that to what extent employees experience emotional exhaustion and display withdrawal behaviors would differ according to their personal beliefs in a just world. From this assumption, whether employees' personal beliefs in a just world moderate the relationship of workplace incivility, emotional exhaustion and withdrawal was also tested.

\section{Research Questions:}

Does workplace incivility have a positive effect on withdrawal?

Does emotional exhaustion mediate the relationship between workplace incivility and withdrawal?

Do employees' personal beliefs in a just world moderate the relationship of workplace incivility and emotional exhaustion?

Do employees' personal beliefs in a just world moderate the indirect effect of workplace incivility on withdrawal?

\section{Methodology}

Field study was conducted on 355 non-manager employees working in administrative units of manufacturing firms operating in Malatya 1. Organized Industrial Zone. Survey method was used and data collection was performed by convenience sampling. Workplace incivility was measured by the 7-item unidimensional scale developed by Cortina et.al. (2001). Emotional exhaustion was assessed by the instrument developed by Maslach and Jackson (1981). Employees' personal beliefs in a just world was measured by 7-item unidimensional scale developed by Dalbert (1999) and withdrawal was assessed by the instrument developed by Spector et.al. (2006). In order to test research hypotheses; reliability, confirmatory factor, correlation and regression analyses were conducted.

\section{Results and Conclusion}

Study findings have shown that workplace incivility has a positive effect on both emotional exhaustion and withdrawal. In addition, the mediating effect of emotional exhaustion on workplace incivility-withdrawal relationship was found to be significant. Moreover, for employees whose personal beliefs in a just world is low, it was found that workplace incivility has a stronger positive effect on emotional exhaustion; and as personal belief in a just world increases from low to high, the indirect effect of workplace incivility on withdrawal (via emotional exhaustion) decreases.

Although study findings may contribute to the understanding of workplace incivility and its negative outcomes, there exists a number of limitations of the study. First, research data were collected from a single source in a single time 
period. Therefore, inferences of causality cannot be established. Second limitation of the study is that sample of the study consists of non-manager employees working in administrative units of manufacturing firms operating in Malatya; thus, the generalizability of the findings is limited. So, it can be recommended to replicate the study in other organizational contexts and/or occupational groups.

\section{Giriş}

Sanal kaytarma, internetin çalışma saatleri içerisinde iş dışı amaçlar için kullanılması olarak tanımlanabilir (Blanchard ve Henle, 2008; Karataş ve Avc1, 2017). Sanal kaytarmanın iş stresini azaltma, kişisel gelişim ve örgütsel öğrenmeye katkıda bulunma gibi olumlu yönlerinin olduğuna dikkat çekilse de (Anadarajan, Devine ve Simmers, 2004; Henle ve Blanchard, 2008; Lim ve Chen, 2012; Block, 2001; Greenfield ve Davis, 2002); yönetim tarafından sınırlarının belirlenmemesi ve denetim altında tutulmaması halinde verimlilik kayb1, performansta azalma (Liberman vd., 2011; Blanchard ve Henle, 2008; Mercado vd., 2017) ve işgörenin iş akdinin feshi (Yıldız ve Yıldız, 2015; Greenfield ve Davis, 2002) gibi arzu edilmeyen bazı sonuçları beraberinde getirdiği görülmektedir. İşletmelerde uygulanan filtreleme, kontrol ve takip sistemleri sanal kaytarmanın denetim altına alınmasında bir noktaya kadar etkili sonuçlar vermektedir (Glassman vd., 2015). Ancak daha kalıcı çözümler üretilebilmesi açısından sanal kaytarmayı tetikleyen faktörlerin belirlenerek bunların ortadan kaldırılması önem arz etmektedir. Uluslararası yazın incelendiğinde sanal kaytarmanın öncüllerine ilişkin çok sayıda araştırma yapıldığı görülmektedir. Yerli yazında ise söz konusu çalışmaların göreceli olarak daha sınırlı sayıda olduğu söylenebilir. Bu çalışmada, işe yabancılaşma kavramı, sanal kaytarmayı tetiklemesi muhtemel bir öncül olarak ele alınmış; çalışanların örgüte yönelik algıladıkları sosyal mübadele ile ilişkilendirilerek incelenmiştir.

Sosyal Mübadele Kuramı (Blau, 1964), yönetim yazınında iş görenlerin işe ve örgüte yönelik tutum ve davranışları ile işveren-işgören ilişkilerini açılamada sıklıkla başvurulan bir kuramdır. Ancak ilgili yazında, örgütsel destek, lider-üye ilişki kalitesi, duygusal bağl1lık ve psikolojik sözleşmenin sosyal mübadelenin göstergeleri olarak ele alınıp, sosyal mübadelenin dolaylı yoldan ölçüldüğü görülmektedir (Colquitt vd., 2014:599). Colquitt ve arkadaşları (2014), sosyal mübadelenin söz konusu göstergelerle değil doğrudan ölçümünün ilgili kuram doğrultusunda daha doğru ve güvenilir sonuçlar vereceğine dikkat çekmektedir. Son yıllarda da yabancı yazında sosyal mübadelenin doğrudan ölçülerek ele alındığı; öncülleri ve ardıllarına ilişkin yapılan çalışmaların da arttığı ifade edilebilir. Sanal kaytarmaya ilişkin yerli ve yabancı yazın incelendiğinde, sosyal mübadelenin sanal kaytarma ile dolaylı olarak ilişkilendirildiği; psikolojik sözleşme, algılanan örgütsel adalet gibi sanal kaytarma ile ilişkili olduğu tespit edilen faktörlerin Sosyal Mübadele Kuramı (Blau, 1964) çerçevesinde açıklandığı görülmektedir. Bu çalışmada, sosyal 
Algılanan Sosyal Mübadele, İşe Yabancılaşma ve Sanal Kaytarma Davranışlarını Etkiler Mi? Mübadele İdeolojisinin Düzenleyici Rolü

mübadele çalışanların örgüte yönelik öznel değerlendirmeleri üzerinden doğrudan ölçülerek ele alınmış; algılanan sosyal mübadele arttıkça çalışanların hem işe yabancılaşma düzeylerinin hem de sanal kaytarma davranışlarının azalıp azalmadığı test edilmiştir.

Çalışan ve örgüt arasındaki sosyal mübadele ilişkisi, destek, takdir vb. gibi sosyo-duygusal nitelikteki faydaların karşılıklı paylaşımıyla zaman içerisinde gelişmekte; çalışanların işe ve örgüte ilişkin tutum ve davranışlarını olumlu yönde etkilemektedir. Söz konusu olumlu etkiler ve sosyal mübadele iliş̧isinin sürekliliği Karşl1ıklılık İlkesi (Gouldner, 1960) doğrultusunda açıklanmaktadır. Ancak Eisenberger vd. $(1986,1987)$ her çalışanın örgütten elde ettiği kazanımlara eşit derecede duyarlı olmadığını; verdikleri tepkilerin farklılaştığını belirtmektedir. Bazı çalışanlar, örgütün kendilerine yapmış olduğu yatırımlara karşı11k örgüt yararına olacak şekilde daha olumlu iş davranışları sergilerken; bazı çalışanlar ise bu konuda daha kayıtsız kalabilmekte, tutum ve davranışlarında herhangi bir değişim gözlenmemektedir. Bu durum, çalışanların karşı1lıklılık ilkesini benimseme düzeyi olarak tanımlanan mübadele ideolojisi (exchange ideology) ile açıklanmaktadır. Yapılan araştırmalar da (Örn. Witt, 1991; Andrews vd., 2003) çalışanların örgütten elde ettikleri kazanımlara karşılık olarak sergiledikleri tutum ve davranışların mübadele ideolojisi düzeylerine bağlı olarak değiştiğine işaret etmektedir. Mevcut çalışmada, çalışanların mübadele ideolojisi düzeylerinin, işe yabancılaşma ve sanal kaytarma davranışlarında anlamlı bir farklılaşmaya yol açabileceği varsayılmış; algılanan sosyal mübadele-işe yabancılaşma ve algilanan sosyal mübadele-sanal kaytarma ilişkisinde mübadele ideolojisinin düzenleyici bir rol oynayıp oynamadığı incelenmiştir.

Çalışmanın iki açıdan ilgili yazına amprik yönde katkı sağlayacağı düşünülebilir: (1) sosyal mübadelenin doğrudan ölçülerek ele alınması ve sanal kaytarma davranışları ile işe yabancılaşma üzerinde anlamlı bir etkisinin olup olmadığının test edilmesi, (2) uluslararası yazında sıklıkla incelenen ancak yerli yazında kendisine kısıtlı yer bulan mübadele ideolojisinin düzenleyici bir etkiye sahip olup olmadığının incelenmesi. Çalışmanın ilk bölümünde konuya ilişkin teorik çerçeve ve hipotezler sunulmuş; ikinci bölümde elde edilen veriler analiz edilmiş; son bölümde ise araştırma sonuçları değerlendirilmiştir.

\section{Kuramsal Çerçeve}

\section{A. Algllanan Sosyal Mübadele ve Sanal Kaytarma}

Blau (1964), sosyal mübadeleyi soyut, sosyo-duygusal nitelikteki kaynak veya faydaların taraflar arasında karşılıklı paylaşımı olarak tanımlamaktadır (Colquitt vd., 2014; Cropanzano ve Mitchell, 2005). Sosyal mübadele ilişkisi, taraflardan birinin diğerine sosyo-duygusal nitelikte fayda sağlaması (destekleme, takdir ve yardım etme vb.) ile başlamakta, karşı tarafın da aldığına karşılık diğerine fayda sağlaması halinde zamanla taraflar arasında sosyal mübadele ilişkisi gelişmektedir. Söz konusu ilişkide paylaşılan faydalar veya geleceğe dönük beklentiler spesifik olarak tanımlanmamış ve geleceğe yönelik 
herhangi bir taahhütte bulunulmamıştır. Ancak taraflar arasındaki güven ve karşılıklı yatırım sosyal mübadele ilişkisinin sürekliliğini sağlamakta; taraflardan birinin yükümlülügünü yerine getirmemesiyle birlikte mübadele ilişkisi sona ermektedir (Cropanzano ve Mitchell, 2005).

Shore vd. (2006), sosyal mübadele ilişkisinin kurulmasında örgütsel desteğin önemli bir rol oynadığına dikkat çekmektedir. Yapılan araştırmalar, örgütsel desteğin yanı sıra, kişi-örgüt uyumu, lider-üye etkileşimi (Kim vd., 2013); dönüşümcü liderlik (Song vd., 2009) algılanan dağıtımsal ve etkileşimsel adalet (Jiang ve Law, 2013; Rupp ve Cropanzano, 2002); kariyer gelişimine yönelik çalışanlara sunulan teşvikler (Shin vd., 2012) ve örgütün yetkinlik modelinin stratejik açıdan yerinde ve adil bulunmasının (Redmond, 2013) sosyal mübadele algısını olumlu yönde etkilediğini göstermektedir. Bir önceki işverene ilişkin algılanan psikolojik sözleşme ihlalinin ise çalışanların mevcut işverenleriyle sosyal mübadele ilişkisi geliştirmelerinde olumsuz bir etkisinin olduğu belirtilmektedir (Buch vd., 2014).

Algılanan sosyal mübadele, çalışanların hem örgüte hem de işe yönelik tutum ve davranışlarını olumlu yönde etkilemektedir. Algılanan sosyal mübadele arttıkça işe cezbolma (Karagonlar vd., 2015); temel psikolojik ihtiyaçlar doyumu, yaratıcılık (Pan vd., 2017), örgüte güven (Shore vd., 2009); iş tatmini (Kim vd., 2013); örgütsel vatandaşlık ve iş performansı artmakta (Shore vd., 2006); işten ayrılma niyeti (Karagonlar vd., 2015; Shore vd., 2009); işe geç kalma ve devamsızlık da (Shore vd., 2006) azalmaktadır.

Algılanan sosyal mübadelenin sanal kaytarma davranışları üzerinde negatif yönde bir etkiye sahip olacağ 1 düşünülmektedir. Sanal kaytarma, bilgi iletişim teknolojileri ve internetin mesai saatleri içerisinde kişisel amaçlar için kullanılması olarak tanımlanmaktadır (Karataş ve Avc1, 2017). Sanal kaytarmanın iş stresini azaltma, bireysel gelişim ve öğrenmeyi kolaylaştırma vb. gibi bir takım olumlu yönlerinin olabileceğine dikkat çekilse de (Blanchard ve Henle, 2008; Anadarajan vd., 2004; Block, 2001; Greenfield ve Davis, 2002); bazı araştırmacılar (Lim, 2002; Robinson ve Bennett, 1995) tarafından üretkenlik karşıtı bir iş davranışı olarak kavramsallaştırılmaktadır.

Sanal kaytarmaya ilişkin öne sürülen boyutlar çeşitlidir. Ancak yapılan araştırmalarda ağırlıklı olarak Blanchard ve Henle (2008)'in öne sürmüş olduğu sınıflandırmanın kullanıldığı söylenebilir. Blanchard ve Henle (2008), sanal kaytarmay1 önemli ve önemsiz sanal kaytarma olmak üzere iki boyutta ele almaktadır. Kişisel e-postaları kontrol etme, internetten spor ve haber sitelerini ziyaret etme gibi kısa süreli ve göreceli olarak daha önemsiz davranışlar önemsiz sanal kaytarma boyutunu ifade etmektedir. Önemli sanal kaytarma boyutu ise, sohbet odalarına katılma, internetten müzik indirme, bahis oynama, kişisel web sayfası düzenleme, erişkin sitelerini ziyaret etme vb. gibi daha uzun süreli ve uygun olmayan faaliyetleri içermektedir. Blanchard ve Henle (2008) önemli sanal kaytarma boyutunu üretkenlik karşıtı bir iş davranışı olarak nitelendirirken; 
Algılanan Sosyal Mübadele, İşe Yabancılaşma ve Sanal Kaytarma Davranışlarını Etkiler Mi? Mübadele İdeolojisinin Düzenleyici Rolü

önemsiz sanal kaytarmanın göreceli olarak daha tolere edilebilir olduğunu belirtmekte ve işyerindeki sosyal normların önemsiz sanal kaytarma davranışları üzerinde önemli bir rol oynadığına dikkat çekmektedir.

Sanal kaytarmanın öncüllerine ilişkin yapılan araştırmalara göre, dış denetim odakl11ık (Blanchard ve Henle, 2008); dişadönüklük, duygusal dengesizlik (Örücü ve Aksoy, 2018); örgütsel adaletsizlik (Lim, 2002; Lim ve Teo, 2005), iş tatminsizliği (Çavuşoğlu ve Palamutçuoğlu, 2017), duyarsızlaşma (Yıldırım, 2018) ve örgütsel sinizm (Özdemir, 2017) sanal kaytarmayı pozitif yönde etkilemektedir. İşe tutkunluk, öz-kontrol, duygusal dengelilik, uzlaşılabilirlik ve sorumluluk düzeyinin ise sanal kaytarma ile negatif yönde ilişkili olduğu görülmektedir (Mercado vd., 2017).

Örgüt ve çalışan arasındaki sosyal mübadele ilişkisinin, uzun vadeli olması, karşı1ıklı güvene dayanması ve sosyo-duygusal nitelikte karşılık 1 yatırımı içermesi nedeniyle sanal kaytarma davranışlarını negatif yönde etkileyeceği düşünülmektedir. Algılanan sosyal mübadele arttıkça; çalışanların bu durumu örgüt nezdinde değerli olduklarının; iyilik ve refahlarının örgüt tarafından dikkate alındığının bir göstergesi olarak değerlendirecekleri; dolayısıyla da elde ettikleri kazanımlara karşılık örgüt yararına olacak nitelikte tutum ve davranışlar sergileyecekleri ifade edilebilir. Nitekim yapılan araştırmalar da algılanan sosyal mübadelenin örgütsel bağl1lık, örgütsel vatandaşl1k, örgütsel güven ve örgütsel değişim sürecine bağlllık gibi pek çok olumlu tutum ve davranışı beraberinde getirdiğini göstermektedir (Shore vd., 2006; Shore vd., 2009). Bunun yanı sıra, sosyal mübadelenin işe yönelik içsel motivasyonu artırdığ 1 ; iş tatmini, işe cezbolma ve iş performansını da pozitif yönde etkilediği görülmektedir (Kim vd., 2013; Karagonlar vd., 2015; Shore vd.., 2006). Dolayısıyla, algılanan sosyal mübadele arttıkça, çalışanların sadece örgüte yönelik değil; işe iliş̧in tutum ve davranışlarının da olumlu yönde değiş̧eceği böylelikle daha az sanal kaytarma davranışları sergileyecekleri düşünülebilir:

$\mathbf{H}_{1}$ : Algılanan sosyal mübadele önemsiz kaytarma davranışlarını negatif yönde etkiler.

$\mathbf{H}_{2}$ : Algılanan sosyal mübadele önemli kaytarma davranışlarını negatif yönde etkiler.

\section{B. İse Yabancılaşma}

İşe yabancılaşma, kişinin yaptığı iş ile bağının kopması (Nair ve Vohra, 2009), kişinin beklentileri, ihtiyaç ve değerleri ile uyuşmayan çalışma şartları nedeniyle yaşadığ psikolojik durum (Mottaz, 1981) ya da çalışma hayatına ve çalışmaya ilişkin ilgisizlik (Hirschfeld ve Field, 2000) olarak tanımlanabilir. Seeman (1959) işe yabancılaşmayı anlamsızlık, güçsüzlük, normsuzluk, sosyal izolasyon ve kendine yabancılaşma olmak üzere 5 boyuttan oluşan çok boyutlu bir kavram olarak ele almaktadır. Anlamsızlık, işin çalışan nezdinde bir anlam ifade etmemesi; güçsüzlük, çalışanın örgütsel çevre üzerinde kontrol duygusundan yoksun olması, sosyal izolasyon, tatminkâr insan ilişkileri kuramama; normsuzluk, referans alınacak ilke ve kuralların bulunmayışı ve son 
olarak kendine yabancılaşma ise işin çalışan nezdinde manevi açıdan ödüllendirici bir nitelik taşımaması olarak ifade edilebilir. Chiaburu ve arkadaşlarının (2014) yapmış olduğu meta-analiz sonuçları, yapılan işin karakteristik özelliklerinden ziyade sosyal faktörlerin; örneğin örgütsel destek ve destekleyici liderliğin işe yabancılaşmayı azaltmada belirleyici bir rol oynadığını göstermektedir. Bunun yanı sıra, otokratik yönetim tarzı (Kanten ve Ülker, 2014), örgütsel sinizm (Çivilidağ, 2015); kişi-örgüt uyumsuzluğu (Mendoza ve Lara, 2007); işyerindeki tatminkar olmayan insan ilişsileri (Nair ve Vohra, 2010) işe yabancılaşmayı tetiklemekte; otantik liderlik (Öcal ve Barın, 2016), dönüşümcü liderlik (Sarros vd., 2002) ve lider üye etkileşimi (Tanrıverdi ve Kahraman, 2016); örgüt içerisindeki güven ve örgüte uyum sağlama düzeyi (Özbek, 2011) ise işe yabancılaşmayı negatif yönde etkilemektedir.

İşe yabancılaşma; mevcut iş koşulları ile çalışanın ihtiyaç ve beklentileri arasında bir uyuşmazlık olması halinde ortaya çıkmakta (Mottaz, 1981); kişi psikolojik olarak kendisini yaptığı işten ayrıştırmaktadır (Banai vd., 2004). İlgisizlik, anlamsızlık, soyutlanma, geri çekilme, soğuma, ilişki kopukluğu gibi duygu ve davranışların yabancılaşmanın göstergeleri olduğu görülmektedir (Tutar, 2010:178). Araştırmalar, işe yabancılaşma arttıkça; iş tatmini, görev performans1, örgütsel bağl1lık, örgütsel vatandaşl1k ve örgütsel özdeşleşmenin azaldığını; işten ayrılma niyetinin de arttığını göstermektedir (Chiaburu vd., 2014). Ayrıca, işe yabancılaşmanın örgütsel adalet algısını olumsuz yönde etkilediği (Turgut ve Kalafatoğlu, 2016), üretkenlik karşıtı iş davranışlarını tetiklediği (Shantz vd., 2015); duygusal tükenmişlik ile pozitif; öznel iyi oluşla da negatif yönde ilişkili olduğu (Shantz vd., 2014) görülmektedir.

İşe yabancılaşmanın olumsuz sonuçlarından birisinin de sanal kaytarma davranışları olacağı ifade edilebilir. İşe yabancılaşma arttıkça çalışanların işe yönelik motivasyonları azalmakta; yaptıkları işi para kazanma vasıtası olarak araçsallaştırmakta ve aktif bir biçimde işe katılımdan ve sorumluluk üstlenmekten kaçınmaktadırlar (Shephard, 1970:209). Söz konusu motivasyon düşüklügü ve işe ilişkin ilgisizliğin çalışanları sanal kaytarma davranışlarına sevk edeceği düşünülebilir. Diğer taraftan, algılanan sosyal mübadelenin işe yabancılaşmayı azaltarak sanal kaytarma davranışlarını da negatif yönde etkileyeceği öngörülmektedir. Çalışan ve örgüt arasındaki sosyal mübadelenin çalışanların işyerindeki temel psikolojik ihtiyaçlarının karşılanmasında, işe yönelik içsel motivasyonlarının artmasında etkili olduğundan (Pan vd., 2017; Kim vd., 2013); çalışanların algıladığı sosyal mübadele arttıkça daha az işe yabancılaşma yaşayacakları; azalan işe yabancılaşmayla birlikte daha düşük düzeyde sanal kaytarma davranışı sergileyecekleri beklenebilir.

$\mathbf{H}_{3}$ :İşe yabancılaşma, algılanan sosyal mübadele-önemsiz sanal kaytarma davranışları ilişkisinde aracılık etkisine sahiptir.

$\mathbf{H}_{4}$ :İşe yabancılaşma, algılanan sosyal mübadele-önemli sanal kaytarma davranışları ilişkisinde aracılık etkisine sahiptir. 
Algılanan Sosyal Mübadele, İşe Yabancılaşma ve Sanal Kaytarma Davranışlarını Etkiler Mi? Mübadele İdeolojisinin Düzenleyici Rolü

\section{Mübadele İdeolojisinin Düzenleyici Rolü}

Mübadele/değişįm ideolojisi (exchange ideology); mübadele ilişkisinde tarafların Karşıllıklılık İlkesini (Gouldner, 1960) benimseme düzeyi olarak tanımlanmaktadır (Eisenberger vd., 1986; Eisenberger vd., 2001). Sosyal mübadele ilişkisinin süreklilik kazanmasında ve taraflar arasındaki güvenin pekişmesinde Karşı1ıklılık İlkesi (Gouldner, 1960) önemli bir rol oynamaktadır (Shore vd., 2006; Shore vd., 2009). Ancak her çalışanın karşıllklılık ilkesini eşit düzeyde benimsemediği (Cropanzano ve Mitchell, 2005); örgütten birtakım kazanımlar elde etseler bile verdikleri tepkilerin farklı olduğu görülmektedir. Mübadele ideolojisi yüksek çalışanlar, kendilerine yapılan yatırıma karşılık, örgüt yararına olacak şekilde daha olumlu iş davranışları sergilerken; mübadele ideolojisi düşük çalışanlar, bu konuda daha kayıtsız kalabilmekte, tutum ve davranışlarında herhangi bir değişim gözlenmemektedir. Mübadele ideolojisi yüksek çalışanların örgütten elde ettikleri kazanımlara karşı daha duyarlı oldukları ve daha olumlu karşıllk verdikleri; mübadele ideolojisi düşük çalışanların ise örgütün kendilerine sunmuş olduğu faydalar doğrultusunda iş davranışlarını değiştirmedikleri ve/veya şekillendirmedikleri görülmektedir (Eisenberger vd., 1986; 1987). Araştırmalar, yüksek düzeyde mübadele ideolojisine sahip çalışanların; algıladıkları örgütsel destek arttıkça daha fazla rol dışı iş performansı (Witt, 1991) ve örgütsel vatandaşlık davranışı sergilediklerini (Ladd ve Henry, 2000); kendilerini örgüte karşı daha fazla borçlu/yükümlü hissettiklerini göstermektedir (Eisenberger, vd., 2001). Bunun yanı sira, algıladıkları dağıtımsal adaletsizlik arttıkça örgüte olan duygusal bağlılıklarının daha fazla azaldığı (Witt, Kacmar ve Andrews, 2001); örgütü politik bulmaları halinde de daha az işte kalma niyetine sahip oldukları (Andrews vd., 2003) görülmektedir.

Mübadele ideolojisinin, algılanan sosyal mübadele-işe yabancılaşma ve algılanan sosyal mübadele-sanal kaytarma ilişkisinde anlamlı bir farklılaşmaya yol açacağı beklenmektedir. Mübadele ideolojisi yüksek çalışanların örgütten elde ettikleri kazanımlara karşı daha duyarlı olmaları ve kendilerine sağlanan faydalara paralel olarak tutum ve davranışlarını şekillendirmeleri nedeniyle; algıladıkları sosyal mübadele arttıkça hem daha az işe yabancılaşma yaşayabilecekleri hem de daha az sanal kaytarma davranışı sergileyecekleri söylenebilir. Mübadele ideolojisi düşük olan çalışanlarda ise algıladıkları sosyal mübadelenin işe yabancılaşma ve sanal kaytarma davranışları üzerindeki olumsuz etkisinin daha düşük olacağı beklenmektedir. Buradan hareketle geliştirilen hipotezler aşağıdaki gibidir:

H$_{5}$ : Mübadele ideolojisi, algılanan sosyal mübadele-işe yabancılaşma ilişkisinde düzenleyici bir rol oynar.

$\mathbf{H}_{6}$ : Mübadele ideolojisi, algilanan sosyal mübadele-önemsiz sanal kaytarma ilişkisinde düzenleyici bir rol oynar. 
$\mathbf{H}_{7}$ : Mübadele ideolojisi, algılanan sosyal mübadele-önemli sanal kaytarma ilişkisinde düzenleyici bir rol oynar.

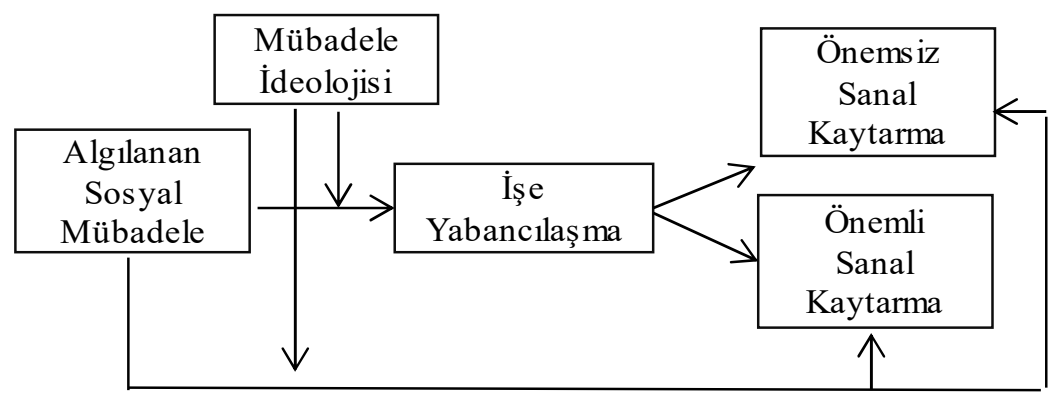

Şekil 1: Kavramsal Model

\section{Yöntem}

\section{A. Araştırma Yöntemi ve Örneklem}

Saha araştırması, Malatya iline bağlı merkez ve bir ilçe belediyesinde idari birimlerde çalışan personel üzerinde yürütülmüsştür. Kolayda örneklem ve kartopu yöntemiyle 243 kişiye ulaşılmıştır. Anket formlarının bir kısmı elden dağıtılırken bir kısmı da elektronik posta yoluyla katılımcılara ulaştırılımıştır. 239 kişiden geri dönüş sağlanmış; 2 anket eksik doldurulması sebebiyle elenmiştir. Değerlendirilmeye alınan 237 anket formundan elde edilen veriler; güvenilirlik, doğrulayıcı faktör, korelasyon ve hiyerarşik regresyon analizleri yapılarak ile incelenmiştir.

Katılımcıların \%69,7'si erkek; \%30,3'ü kadın olup \%65'i evlidir. Yarıdan fazlası lisans mezunu (\%52,3); \%22,3'ü lise; \%12,7'si ön lisans ve yine \%12,7'si de lisansüstü mezunudur. Örneklemin \%30,1'i 30 yaşın altında yer almaktadır. 30-34 yaş aralığında olanların oranı \%27,3; 35-39 yaş aralığında olanların oranı $\% 22,8 ; 40-44$ yaş aralığında olanların oran $1 \% 5,1 ; 45$ yaş ve üzeri olanların oranı ise \%14,7'dir. Katılımcıların \%17,7'si 3 yıldan az;. \%24,9'u 3-5 yıl; \%27,4'ü 69 y1l; \%15,2'si 10-14 yıl; \%14,8'i de 15 y1l ve üzeri bir süredir mevcut işlerinde çalıştıklarını belirtmişlerdir.

\section{B. Kullanılan Ölçekler}

Çalışanların algıladığı sosyal mübadelenin ölçümü için Shore vd. (2006) tarafindan geliştirilen ve 8 ifadeden oluşan ölçek kullanılmıştır. Ölçek, Göktepe (2012) tarafından Türkçe'ye çevrilmiştir (Örnek madde: "Çalıştı̆ı̆ kurum benim için anlamlı ve önemli yatırımlar yapmışıı"'). Ölçek 5 noktalı Likert tipi olup yanıtlar 1=Kesinlikle Katılmıyorum ve 5=Kesinlikle Katılıyorum aralığında derecelendirilmiştir. Yapılan doğrulayıcı faktör analizi sonucunda ölçeğin uyum indeks değerleri; $\chi^{2} / \mathrm{df}=1,416 ; \quad \mathrm{RMSEA}=0,023 ; \quad \mathrm{GFI}=0,942 ; \quad \mathrm{NFI}=0,953$; $\mathrm{CFI}=0,971$ olarak bulunmuştur. Elde edilen sonuçlara göre ölçeğin uyum indeks değerlerinin kabul edilebilir sınır değerlerin üzerinde olduğu; modele iyi uyum sağladığı, tek boyutlu yapının doğrulandığı ifade edilebilir [İyi uyum indeks 
Algılanan Sosyal Mübadele, İşe Yabancılaşma ve Sanal Kaytarma Davranışlarını Etkiler Mi? Mübadele İdeolojisinin Düzenleyici Rolü

değerleri, sirasiyla: $\chi 2 / \mathrm{df}=\leq 3$ ve; RMSEA $=\leq 0,05 ; \mathrm{GFI} \geq 0,90 ; \mathrm{NFI} \geq 0,95 ; \mathrm{CFI} \geq$ 0,97); Meydan ve Şeşen (2015:37)]. Ölçeğe ilişkin cronbach alpha değeri ise 0,914 'tür.

İşe yabancılaşmanın ölçümü için Hirschfeld ve Field (2000) tarafindan geliştirilen; tek boyutlu ve 10 maddeden oluşan ölçek kullanılmıştır. Ölçeğin Türkçe formu için Özbek (2011) çalışmasından yararlanılmıştır (Örnek madde: "Ne kadar sıkı çalıştığının bir önemi yok, nasıl olsa istediklerini elde edemeyeceksin"). Ölçek 5 noktalı Likert tipi olup yanttlar 1=Kesinlikle Katılmıyorum ve $5=$ Kesinlikle Katılıyorum aralığında derecelendirilmiștir. Yapılan doğrulayıcı faktör analizi sonucunda; ölçeğin ilk maddesi olan "Yaşamak için çalışan kişiler, idareciler tarafindan çıkar amaçlı kullanılmaktadır" ifadesinin düşük faktör yüküne sahip olduğu $(<0,15)$ belirlenmiş ve analizden çıkarılmıştır. Geriye kalan 9 maddeye uygulanan doğrulayıc faktör analizi sonucunda ölçeğin iyi uyum indeks değerlerine sahip olduğu tespit edilmiştir. Elde edilen değerler: $\chi 2 / \mathrm{df}=1,802$; RMSEA $=0,052$; $\mathrm{NFI}=0,994$; GFI $=0,992$ ve $\mathrm{CFI}=0,998$ şeklindedir. Cronbach alpha değeri ise 0,886 olarak bulunmuştur.

Çalışanların ne sıklıkta sanal kaytarma davranışı sergilediklerini belirlemek üzere Blanchard ve Henle (2008) tarafından geliştirilen ölçek kullanılmıştır. Ölçek önemli ve önemsiz sanal kaytarma olmak üzere iki boyuttan oluşmaktadır (Örnek maddeler: önemsiz sanal kaytarma: "İ̧̧e ilgili olmayan kişisel e-postalar gönderirim"; önemli sanal kaytarma: "Internetten müzik indiririm”). Ölçeğin Türkçe'ye uyarlaması Özdemir (2017) tarafinda yapılmıştır. Ölçek 5 noktalı Likert tipi olup yanıtlar $1=$ Hiçbir zaman ve $5=$ Çok sık aralığında derecelendirilmişsir. Yapılan birinci düzey doğrulayıcı faktör analizi sonucunda önemsiz sanal kaytarmaya ilişkin uyum indeks değerleri; $\chi 2 / \mathrm{df}=2,824$; RMSEA $=0,078 ; \quad \mathrm{NFI}=0,940 ; \mathrm{GFI}=0,918 ; \mathrm{CFI}=0,952$ olarak bulunmuştur. Önemli sanal kaytarmaya ilişkin elde edilen uyum indeks değerleri ise, $\chi 2 / \mathrm{df}=1,980 ; \mathrm{RMSEA}=0,064 ; \mathrm{NFI}=0,979 ; \mathrm{GFI}=0,976$ ve $\mathrm{CFI}=0,989$ şeklindedir. Böylelikle, ölçeğin her iki alt boyuna ilişkin indeks değerlerinin kabul edilebilir sınırlar içerisinde yer aldığı belirlenmiştir [Kabul edilebilir uyum indeks değerleri, sirasıyla: $\chi 2 / \mathrm{df}=\leq 4-5$; RMSEA $=0,06-0,08$; GFI $=0,89-0,85$; NFI $=0,94$ 0,$90 ;$ CFI $\geq 0,95$ ); Meydan ve Şeşen (2015:37)]. Önemsiz sanal sanal kaytarmaya ilişkin elde edilen cronbach alpha değeri 0,878; önemli sanal kaytarma için ise 0,914'tür.

Çalışanların mübadele ideolojisinin ölçümü için Eisenberger ve arkadaşları (1986) tarafından geliştirilen ölçek kullanılmıştır. Ölçek tek boyutlu olup 5 maddeden oluşmaktadır. Ölçek, her iki dili ve kültürü bilen üç öğretim üyesi tarafından çeviri-geri çeviri yöntemiyle (Brislin, 1986) Türkçe'ye tercüme edilmiştir (Örnek madde: "Örgüt tarafından kendisine kötü davranılan bir çalışan, işteki çabasını azaltmalıdı’”). Yapılan doğrulayıcı faktör analizi ile ölçeğin tek boyutlu yapısı doğrulanmış $(\chi 2 / \mathrm{df}=1,944 ; \quad \mathrm{RMSEA}=0,065 ; \quad \mathrm{GFI}=0,995$; $\mathrm{NFI}=0,990$ ve $\mathrm{CFI}=0,993)$ ve cronbach alpha değeri 0,827 olarak bulunmuştur. 
Şeyda Nur SEÇKİN

\section{Bulgular}

Araştırma hipotezlerini test etmeden önce değişkenler arasında anlamlı bir ilişki olup olmadığını belirlemek üzere korelasyon analizi yapılmıştır. Elde edilen sonuçlar Tablo 1'de yer almaktadır:

Tablo 1. Korelasyon Analizi Sonuçları

\begin{tabular}{|c|c|c|c|c|c|c|c|c|c|c|}
\hline Değişkenler & 1 & 2 & 3 & 4 & 5 & 6 & 7 & 8 & 9 & 10 \\
\hline 1. Yaş & - & & & & & & & & & \\
\hline 2. Cinsiyet ${ }^{\mathrm{a}}$ & 10 & - & & & & & & & & \\
\hline 3. Medeni Durum ${ }^{\mathrm{b}}$ &, $57 * *$ & ,03 & - & & & & & & & \\
\hline 4. Eğitim &,$- 28 * *$ &,- 17 &,- 14 & - & & & & & & \\
\hline 5. Çalışma Süresi &, $57 * *$ &, 04 &, $32 * *$ &, 12 & - & & & & & \\
\hline 6. Alg. Sosyal M. &, 01 &,- 06 &, 04 & 02 &,- 08 & - & & & & \\
\hline 7. İşe Yabancılaş. &,$- 25 * *$ &, 01 &,- 04 &, $21 *$ &, 05 &,$- 39 * *$ & - & & & \\
\hline 8. Önemsiz S. K. &,- 07 &, 04 &,- 12 &, 11 &,- 06 &,- 17 &,- 09 & - & & \\
\hline 9..Önemli S. K. &,- 10 &,- 16 &,- 05 &, $23 * *$ &, 07 &,$- 24 * *$ &,$- 33 * *$ &, $73 * *$ & - & \\
\hline 10.Mübadele İ. &,- 04 &,- 08 &,$- 19 *$ &,$- 21 *$ &,- 09 &,- 16 &,$- 22 *$ &, $19 *$ &, 17 & - \\
\hline Ortalama & & & & & & 3,04 & 3,11 & 2,98 & 2,15 & 2,47 \\
\hline Standart Sapma & & & & & &, 57 & ,89 & ,66 &, 81 & ,67 \\
\hline
\end{tabular}

Tablo 1'de yer alan değişkenlere ilişkin aritmetik ortalamalar incelendiğinde, katılımcıların algıladıkları sosyal mübadele $(\mu=3,04)$ ve işe yabancılaşma $(\mu=3,11)$ düzeylerine ilişkin görüşlerinde kararsız oldukları görülmektedir. Önemli sanal kaytarma davranışlarını nadiren $(\mu=2,15)$; önemsiz sanal kaytarma davranışlarını da ara ara $(\mu=2,98)$ sergilediklerini beyan etmiş̧lerdir. Katılımcıların mübadele ideolojisi düzeyleri ise ortalama değerin altındadır $(\mu=2,47)$. Korelasyon analizi sonuçları incelendiğinde, algılanan sosyal mübadelenin işe yabancılaşma ve önemli sanal kaytarma davranışları ile negatif yönde ilişkili olduğu görülmektedir $[(\mathrm{r}=-, 39 ; \mathrm{p}<0,01) ;(\mathrm{r}=-$ ,24; $p<0,01)$ sirasiyla]. Algılanan sosyal mübadele ile önemsiz sanal kaytarma davranışları arasında ise istatistiki açıdan anlamlı bir ilişki tespit edilememiştir $(\mathrm{r}=-, 17 ; \mathrm{p}>0,05)$. Böylelikle, $\mathbf{H}_{1}, \mathbf{H}_{3}$ ve $\mathbf{H}_{\mathbf{6}}$ hipotezleri reddedilmiştir. İşe yabancılaşmanın hem önemli sanal kaytarma davranışı hem de mübadele ideolojisi ile negatif yönde ilişkili olduğu görülmüştür $[(\mathrm{r}=-, 33 ; \mathrm{p}<0,01) ;(\mathrm{r}=-, 22$; $\mathrm{p}<0,05)$ sırasıyla]. İşe yabancılaşma ile önemsiz sanal kaytarma davranışı arasında ise istatistiki açıdan anlamlı bir ilişki tespit edilememiştir ( $\mathrm{r}=-, 09$; $\mathrm{p}>0,05$ ). Elde edilen bir diğer sonuç ise demografik değişkenlerden sadece yaş ve eğitim düzeyinin işe yabancılaşma, önemli sanal kaytarma ve mübadele ideolojisi ile ilişkili olduğu yönündedir. Buna göre, eğitim düzeyi ile işe yabancılaşma ve önemli sanal kaytarma davranışı arasında pozitif $[(\mathrm{r}=, 21$; 
Algılanan Sosyal Mübadele, İşe Yabancılaşma ve Sanal Kaytarma Davranışlarını Etkiler Mi? Mübadele İdeolojisinin Düzenleyici Rolü

$\mathrm{p}<0,05) ;(\mathrm{r}=, 23 ; \mathrm{p}<0,01)$ sirasiyla]; mübadele ideolojisi ile de negatif yönde bir ilişki bulunmaktadır $(\mathrm{r}=-, 21 ; \mathrm{p}<0,05)$. Yaş ise işe yabancılaşma ile negatif yönde ilişkilidir $(r=-, 25 ; p<0,01)$.

Algılanan sosyal mübadelenin, işe yabancılaşma ve önemli sanal kaytarma üzerinde anlamlı bir etkisinin olup olmadığını test etmek üzere hiyerarşik regresyon analizi yapılmıştır. Algılanan sosyal mübadele ve işe yabancılaşma ile ilişkili olduğu tespit edilen yaş ve eğitim kontrol grubu olarak belirlenmiş; kategorik değişkenler olması sebebiyle kukla değişkenlere dönüştürülmüş̧; regresyon analizine ilk adımda dahil edilmiştir [(Lisans ve Lisansüstü $=1$; Lise ve Önlisans $=0) ;(35$ yaş altı $=1 ; 35$ yaş ve üstü $=0)$ ]. Elde edilen sonuçlar Tablo 2 'deki gibidir:

Tablo 2. Hiyerarşik Regresyon Analizi

\begin{tabular}{llrll}
\hline & \multicolumn{2}{c}{ İşe Yabancilaşma } & \multicolumn{2}{c}{ Önemli Sanal Kaytarma } \\
\hline & \multicolumn{1}{c}{$\beta$} & S.H & \multicolumn{1}{c}{$\beta$} & S.H \\
\hline Sabit & $3,034^{* * *}$ &, 271 & $1,592^{* * *}$ &, 249 \\
Yaş $^{\mathrm{a}}$ &,$- 201^{* *}$ &, 037 &,- 042 &, 034 \\
Eğitim $^{\mathrm{b}}$ &, $151^{*}$ &, 056 &, $228^{* * *}$ &, 052 \\
\hline $\mathrm{R}^{2} /$ Düzelt. $\mathrm{R}^{2}$ & \multicolumn{2}{c}{, $081 /, 073$} & \multicolumn{2}{c}{, $060 /, 052$} \\
\hline Algilanan sosyal mübadele &,$- 402^{* * *}$ &, 088 &,$- 136^{*}$ &, 093 \\
İşe yabanc1laşma & \multicolumn{2}{c}{, $254^{* * *}$} &, 063 \\
\hline $\mathrm{R}^{2} /$ Düzelt. $\mathrm{R}^{2} / \Delta$ Düzelt. $\mathrm{R}^{2}$ &, $242 /, 233 /, 160$ & \multicolumn{2}{c}{, $165 /, 151 /, 099$}
\end{tabular}

${ }^{\mathrm{a}}$ (35 yaș altı $=1,35$ yas ve üzeri $\left.=0\right)$; ${ }^{\mathrm{b}}($ Lisans ve Lisansüstü $=1$, Lise ve Önlisans $=0) ;{ }^{*} \mathrm{p}<0,05$;

$* * \mathrm{p}<0,01 ; * * * \mathrm{p}<0,001 ; \mathrm{S} . \mathrm{H}$ : standart hata; $\beta$ : standardize edilmiş beta katsayısı

Yapılan hiyerarşik regresyon analizi sonucunda, 35 yaşın altındaki katılımcıların işe yabancılaşma düzeylerinin 35 yaş ve üzeri katılımcılara kıyasla daha düşük olduğu $(\beta=-, 201 ; p<0,01)$; lisans ve lisansüstü mezunların da lise ve ön lisans mezunlarına kıyasla işe hem yabancılaşma düzeylerinin $(\beta=, 151$; $\mathrm{p}<0,05)$ hem de önemli sanal kaytarma davranışı sergileme sıklıklarının $(\beta=, 228$; $\mathrm{p}<0,001)$ daha yüksek olduğu görülmüştür. Bunun yanı sıra, algılanan sosyal mübadelenin işe yabancılaşma ve önemli sanal kaytarmayı negatif yönde etkilediği belirlenmiştir [sırasıyla; $(\beta=-, 402 ; \mathrm{p}<0,001) ;(\beta=-, 136 ; \mathrm{p}<0,05)$ ]. Böylelikle $\mathbf{H}_{2}$ hipotezi ("Algılanan sosyal mübadele önemli sanal kaytarma davranışlarını negatif yönde etkiler") desteklenmiştir. Son olarak, işe yabancılaşmanın da önemli sanal kaytarma üzerinde pozitif yönde bir etkisi olduğu tespit edilmiştir $(\beta=, 254 ; p<0,001)$.

İşe yabancılaşmanın algılanan sosyal mübadele-önemli sanal kaytarma ilişkisinde aracılık etkisine sahip olup olmadığı, PROCESS Macro 2.16 Model 4 aracılığıla önyükleme (bootstrapping) yöntemi $(\mathrm{n}=10.000)$ kullanılarak incelenmiştir. Analiz sonucunda, işe yabancılaşmanın aracılık etkisinin anlamlı olduğu tespit edilmiş̧ir ( $\mathrm{CI}=\% 95$; BootLLCI $=-, 2420$; BootULCI $=-, 0626)$. Böylelikle, $\mathbf{H}_{4}$ hipotezi desteklenmiştir. 
Mübadele ideolojisinin; hem algılanan sosyal mübadele-işe yabancılaşma hem de algılanan sosyal mübadele-önemli sanal kaytarma ilişkisinde düzenleyici bir etkisinin olup olmadığını belirlemek üzere düzenlenmiş hiyerarşik regresyon analizi gerçekleştirilmiştir. Analiz öncesinde bağımsız ve düzenleyici değişkenler (algılanan sosyal mübadele ve mübadele ideolojisi) standardize edilmiştir. İlk aşamada kontrol grubu olarak belirlenen yaş ve eğitim; ikinci aşamada algılanan sosyal mübadele ve mübadele ideolojisi; son aşamada ise oluşturulan etkileşim terimi (algılanan sosyal mübadeleXmübadele ideolojisi) analize girilmiştir. Elde edilen sonuçlar Tablo 3'te yer almaktadır.

Tablo3. Düzenlenmiş Hiyerarşik Regresyon Analizi

\begin{tabular}{lcccc}
\hline & \multicolumn{2}{c}{ İşe Yabancılaşma } & \multicolumn{2}{c}{ Önemli Sanal Kayt. } \\
\hline Sabit & Beta & S.H & Beta & S.H \\
Yaş & $3,034 * * *$ &, 282 & $1,592 * * *$ &, 249 \\
Eğitim &,$- 112 * *$ &, 037 &,- 022 &, 034 \\
\hline $\mathrm{R} / \mathrm{R}^{2}$ &, $130 *$ &, 056 &, $179 * * *$ &, 052 \\
\hline Algılanan sosyal mübadele & \multicolumn{2}{c}{, $284 /, 081$} & \multicolumn{2}{c}{, $244 /, 060$} \\
Mübadele ideolojisi &,$- 393 * * *$ &, 049 &,$- 167 * * *$ &, 049 \\
\hline $\mathrm{R} / \mathrm{R}^{2} / \Delta \mathrm{R}^{2}$ &,$- 246^{* * *}$ &, 051 &, $156 * *$ &, 051 \\
\hline $\mathrm{Alg}$. sosyal müb.Xmübadele ideo. &, $559 /, 312 /, 231$ &, $387 /, 150 /, 090$ \\
\hline $\mathrm{R} / \mathrm{R}^{2} / \Delta \mathrm{R}^{2}$ &, $172 * *$ &, 065 &,- 029 &, 067 \\
\hline *p $<0,05 ; * * \mathrm{p}<0,01 ; * * * \mathrm{p}<0,001 ;$ Beta: standardize edilmemiş beta katsay1s1; S.H: standart hata
\end{tabular}

Tablo 3'te yer alan sonuçlar incelendiğinde, oluşturulan etkileşim teriminin algılanan sosyal mübadele-işe yabancılaşma ilişkisinde istatistiki açıdan anlamlı bir etkiye sahip olduğu görülmektedir (Beta=,172; $\mathrm{p}<0,01$ ). Etkileşim teriminin algılanan sosyal mübadele-önemli sanal kaytarma davranış1 ilişkisinde ise istatistiki açıdan anlamlı bir etkisinin olmadığı tespit edilmiştir (Beta $=-, 029 ; \mathrm{p}>0,05$ ). Böylelikle $\mathbf{H}_{7}$ (Mübadele ideolojisi, algilanan sosyal mübadele-önemli sanal kaytarma ilişkisinde düzenleyici bir etkiye sahiptir") hipotezi reddedilmiştir.

Analizin ikinci aşamasında algılanan sosyal mübadele - işe yabancılaşma ilişkisinin büyük ölçüde çalışanların mübadele ideolojisi düzeylerine bağlı olup olmadığını belirlemek üzere basit eğim testi (Aiken ve West, 1991) yapılmış; mübadele ideolojisinin +1SS ve -1SS değerlerinde regresyon katsayıları hesaplanmıştır. Yapılan analiz sonucunda; mübadele ideolojisi yüksek olan çalışanlarda, algılanan sosyal mübadelenin işe yabancılaşma üzerindeki olumsuz etkisinin daha yüksek (Beta=-,545; $\mathrm{p}<0,001)$; mübadele ideolojisi düşük olan çalışanlarda ise bu etkinin daha düşük (Beta $=-, 202 ; \mathrm{p}<0,05)$ olduğu görülmüştür. Böylelikle, $\mathbf{H}_{5}$ hipotezi desteklenmiştir. 
Algılanan Sosyal Mübadele, İşe Yabancılaşma ve Sanal Kaytarma Davranışlarını Etkiler Mi? Mübadele İdeolojisinin Düzenleyici Rolü

\section{Sonuç}

Elde edilen bulgular değerlendirildiğinde, demografik değişkenlerden sadece eğitim düzeyinin önemli sanal kaytarma davranışları üzerinde anlamlı bir etkisinin olduğu görülmektedir. Buna göre, lisans ve lisansüstü mezunları, lise ve önlisans mezunlarına kıyasla daha fazla önemli sanal kaytarma davranışları sergilemektedir. Yaş, cinsiyet ve çalışma süresi ile önemli-önemsiz sanal kaytarma arasında ise anlamlı bir ilişki tespit edilememiştir. Elde edilen bu sonuç, demografik değişkenlerin sanal kaytarma ile önemsiz addedilebilecek kadar düşük düzeyde ilişkili olduğuna dikkat çeken Mercado vd. (2017) meta-analiz sonuçlarıyla paralellik göstermektedir.

Araştırma sonuçları, algılanan sosyal mübadelenin işe yabancılaşma ve önemli sanal kaytarma davranışları üzerinde negatif yönde bir etkisinin olduğunu göstermektedir. Bir diğer ifadeyle, algılanan sosyal mübadele arttıkça çalışanların hem işe yabancılaşma düzeyleri hem de önemli sanal kaytarma davranışları azalmaktadır. Bunun yanı sıra, işe yabancılaşmanın, önemli sanal kaytarmay1 pozitif yönde etkilediği belirlenmiştir. Elde edilen bu sonuç; işe yabancılaşma-önemli sanal kaytarma arasında pozitif yönlü bir ilişki olduğunu gösteren araştırma sonucuyla (Babadağ, 2018) örtüşmektedir.

Algılanan sosyal mübadele ve işe yabancılaşma ile önemsiz sanal kaytarma davranışları arasında ise anlamlı bir ilişki bulunmamaktadır. Blancard ve Henle (2008), önemli sanal kaytarmayı üretkenlik karşıtı iş davranışı olarak nitelendirirken; önemsiz sanal kaytarmanın daha kısa süreli ve göreceli olarak daha tolere edilebilir olduğunu ve örgüt içindeki sosyal normların önemsiz sanal kaytarma üzerinde belirleyici bir rol oynadığını belirtmektedir. Bununla birlikte, pek çok çalışanın da kişisel e-postaları kontrol etme, internetten haber ve spor sitelerini ziyaret etme gibi kısa süreli önemsiz sanal kaytarma davranışlarını üretkenlik karşıtı bir eylem olarak değerlendirmedikleri ifade edilmektedir. Önemsiz sanal kaytarmanın sergilenmesinde örgüt içindeki sosyal normların başat bir rol oynaması ve çalışanların bizzat kendilerinin de önemsiz sanal kaytarmayı örgüt aleyhine, üretkenlik karşıtı bir davranış olarak nitelendirmemeleri nedeniyle; ilgili değişkenler ile önemsiz sanal kaytarma arasında anlamlı bir ilişki tespit edilememiş olabileceği düşünülebilir.

Elde edilen bir diğer sonuç ise, işe yabancılaşmanın algılanan sosyal mübadele-önemli sanal kaytarma ilişkisinde aracılık etkisine sahip olduğu yönündedir. Çalışanların algıladığı sosyal mübadele arttıkça; işe yabancılaşma düzeyleri azalmakta; azalan işe yabancılaşmayla birlikte de çalışanlar daha az önemli sanal kaytarma davranışı sergilemektedirler.

Bununla birlikte, çalışanların mübadele ideolojisi düzeylerinin, alglanan sosyal mübadele-işe yabancılaşma ilişkisinde düzenleyici bir rol oynadığ 1 tespit edilmiştir. Mübadele ideolojisi yüksek çalışanlarda, algılanan sosyal mübadele arttıkça işe yabancılaşma daha fazla azalmakta; mübadele ideolojisi düşük çalışanlarda ise söz konusu azalma daha düşük bir seviyede gerçekleşmektedir. 
Diğer taraftan, mübadele ideolojisinin algılanan sosyal mübadele-önemli sanal kaytarma ilişkisinde düzenleyici bir rol oynamadığ 1 tespit edilmiştir.

Sanal kaytarma davranışları belli bir sınırın üzerine çıktığında üretkenlik karşıtı iş davranışı olarak nitelendirilmekte; tükenmişlik, düşük performans, zaman ve enerji kaybı gibi arzu edilmeyen sonuçları da beraberinde getirmektedir. Bunun yanı sıra, sanal kaytarmanın diğer üretkenlik karşıtı iş davranışlarıyla da pozitif yönde ilişkili olduğu görülmektedir. İşletmelerde sanal kaytarmanın denetim altına alınmasında elektronik takip ve kontrol sistemleri etkili sonuçlar vermektedir. Fakat çalışanları sanal kaytarmaya sevk eden faktörlerin anlaşılması ve bunların ortadan kaldırılmasının önemli olduğu düşünülmektedir. $\mathrm{Bu}$ araştırmada, algılanan sosyal mübadelenin önemli sanal kaytarmayı hem doğrudan hem de işe yabancılaşma üzerindeki negatif etkisi aracılığıyla olumsuz yönde etkilediği tespit edilmiştir. Dolayısıyla, çalışan ve örgüt arasındaki sosyal mübadele ilişkisinin, çalışanların işe yabancılaşma gibi olumsuz iş tutumlarını etkileme ve önemli sanal kaytarma davranışlarını azaltmada etkili bir araç olabileceği ifade edilebilir. Nitekim, yapılan pek çok araştırma da sosyal mübadelenin çalışanların olumlu iş davranışları sergilemelerinde belirleyici bir rol oynadığını; üretkenlik karşıtı iş davranışlarını da negatif yönde etkilediğini göstermektedir. Örgütün; çalışanların işe ilişkin fikir, görüş veya sorularını dikkate alması, çalışanları yaşadıkları problemleri çekinmeden paylaşmaları yönünde teşvik etmesi ve bireysel gelişimleri için kendilerine firsatlar sunması çalışanlar nezdinde örgüte yönelik sosyal mübadele algısını artıracak; böylelikle çalışanların hem işe hem örgüte ilişkin daha olumlu tutum ve davranışlar sergilemeleri mümkün hale gelecektir. Bilhassa da mübadele ideolojisi yüksek çalışanların, örgütün kendilerine vereceği destek ve sağlayacağı sosyo-duygusal nitelikteki faydalara karşılık işe ilişkin çok daha fazla olumlu tutum ve davranışlar sergileyeceği söylenebilir. Nitekim, bu çalışmada da, mübadele ideolojisi yüksek çalışanların algıladıkları sosyal mübadele arttıkça işe yabancılaşma düzeylerindeki azalmanın çok daha yüksek bir seviyede olduğu tespit edilmiştir. Dolayısıyla, örgüt ve çalışan arasında kurulacak sosyal mübadele ilişkisinin bilhassa da mübadele ideolojisi yüksek çalışanlar üzerinde daha etkili sonuçlar verebileceği ifade edilebilir.

İşletmelerde önemli sanal kaytarma davranışlarının önüne geçilmesinde çalışan ve örgüt arasındaki sosyal mübadele ilişkisi kadar, internet ve bilgi iletişim teknolojilerine ilişkin örgüt politikalarının da önemli bir rol oynadığı ifade edilebilir. İnternet ve bilgi iletişim araçlarının mesai saatleri dahilinde kullanımına ilişkin sınırların açık ve net bir biçimde belirlenmesi (örn. hangi zaman diliminde, ne kadar süre ile); çalışanların bu konuda bilgilendirilmesi ve sınırların ihlali durumunda da caydırıcı nitelikte yaptırımların yürürlüğe konması önem arz etmektedir. Ancak bu konuda biçimsel kuralların yanı sıra, örgüt içindeki sosyal normların da sanal kaytarma üzerinde etkili olduğu görülmektedir. Örneğin Liberman vd. (2011) ve Askew vd. (2018) araştırma sonuçları, yönetici ve çalışma arkadaşlarının sanal kaytarma davranışı 
Algılanan Sosyal Mübadele, İşe Yabancılaşma ve Sanal Kaytarma Davranışlarını Etkiler Mi? Mübadele İdeolojisinin Düzenleyici Rolü

sergilediğini gören ve sanal kaytarmanın oloğan bir davranış olarak nitelendirildiği örgütsel çevrelerde, çalışanların daha fazla sanal kaytarma davranışı sergileme eğiliminde olduklarını göstermektedir. Bu nedenle, tüm çalışanlara bu hususta farkındalık kazandırılıp bilinçlendirilmesinde yöneticilere önemli görevler düştüğü söylenebilir. Örgüt yöneticilerinin bizzat kendilerinin mevcut kural ve politkalar doğrultusunda hareket ederek çalışanlara rol model olması; kurallara riayet etmeyenlere ilişkin yaptırımların geciktirilmeden yürürlüğe konulması ve kimseye ayrıcalık tanınmadan, yaptırımların herkese eşit bir şekilde uygulanması; söz konusu kural ve politikaların örgüt içinde hayata geçirilmeyen formalite süreçler olarak değil; yaptırımı olan normlar olarak kurum içinde yerleşiklik kazanmasına katkı sağlayabilecektir.

Araştırmanın bir takım kısıtları mevcuttur. Çalışma, kesitsel bir araştırma olduğundan elde edilen bulgular neden-sonuç ilişkisi kapsamında yorumlanamamaktadır. Verilerin tek bir kaynaktan toplanması araştırmanın bir diğer kısıtı olup; bu durum, olası bir ortak yöntem hatasını da gündeme getirmektedir (Podsakoff vd., 2003). Veri toplama sürecinde olası bir ortak yöntem hatasının önüne geçmek amacıyla bir takım prosedürel çarelere başvurulmuştur (anket formunda önce bağımlı daha sonra bağımsız değişkenlere ilişkin sorulara yer verilmiş; katılımcıların verdikleri cevapların gizli tutulacağı ve doğru ya da yanlış bir cevap olmadığ 1 yönünde bilgilendirilmiştir) (Podsakoff vd., 2003; Podsakoff vd., 2012). Ayrıca, yapılan Harmon's tek faktör testi sonucunda tek faktörün \%12,080'ini açıkladığ belirlenmiş;; tüm gözlemlenen değişkenlerin tek faktör altında toplandığı modele ilişkin yapılan doğrulayıcı faktör analizi sonucunda da modelin kabul edilebilir uyum indeks değerlerine sahip olmadığı görülmüştür. Son olarak, ölçülmemiş gizil metod faktör tekniğine (unmeasured latent method factor technique) (Podsakoff vd., 2003) başvurulmuş; araştırma modeline, oluşturulan ölçülmemiş gizil metod faktör dahil edildiğinde değişkenler arasındaki korelasyon katsayılarının anlamlı bir değişim göstermediği gözlemlenmiştir. Dolayısıyla, ortak yöntem hatasının bu çalışma için bir önemli bir sorun teşkil etmediği söylenebilir. Konuya ilişkin gelecekte yapılacak çalışmalarda, sanal kaytarmaya ilişkin kurum içindeki sosyal normların ve mevcut kurumsal politikaların ele alınması; algılanan istismarcı yönetim, mobbing ve dışlanmanın sanal kaytarma davranışları üzerinde anlamlı bir etkisinin olup olmadığının incelenmesi araştırmacılara önerilebilir.

\section{Kaynaklar}

Aiken, L. S. ve West, S. G. (1991). Multiple Regression: Testing and interpreting interactions, Thousand Oaks, CA: Sage.

Anandarajan, M., Devine, P. ve Simmers, C. A. (2004) "A Multidimensional Sealing Approach to Personal Web Usage in the Workplace", M. Anandarajan ve C. A. Simmers (eds.), A Personal Web usage in the 
Workplace: A Guide to Effective Human Resources Management, Hensey, Information Science Publishing.

Andrews, M. C., Witt, L. A., ve Kacmar, K. M. (2003). "The interactive effects of organizational politics and exchange ideology on manager ratings of retention", Journal of Vocational Behavior, Vol.62, ss.357-369.

Askew, K. L., Illie, A., Bauer, J. A., Simonet, D. V., Buckner, J. E. ve Robertson, T. A. (2018). "Disentangling How Coworkers and Supervisors Influence Employee Cyberloafing: What Normative Information Are Employees Attending To?", Journal of Leadership \& Organizational Studies, https://doi.org/10.1177/1548051818813091.

Blanchard, A. L. ve Henle, C. A. (2008). "Correlates of different forms of cyberloafing: The role of norms and external locus of control", Computers in Human Behavior, Vol.24, ss.1067-1084.

Blau, P. (1964). Exchange and power in social life, Free Press, New York.

Block, W. (2001). "Cyberslacking, Business Ethics and Managerial Economics", Journal of Business Ethics, 33(3), ss.225-231.

Brislin, R. W. (1986). "The wording and translation of research instruments", W. J. Lonner ve J.W. Berry (Eds.), Field methods in cross-cultural research, Beverly Hills, CA: Sage, ss.137-164.

Buch, R., Kuvaas, B., Shore, L., ve Dysvik, A. (2014). "Once bitten, twice shy? Past breach and present exchange relationships", Journal of Managerial Psychology, 29(8), ss.938-952.

Chiaburu, D. S., Thundiyil, T. ve Wang, J. (2014). "Alienation and its correlates: A meta-analysis", European Management Journal, 32, ss.24-36.

Colquitt, J. A., Baer, M. D., Long, D. M. ve Halvorsen-Ganepola, M. D. K. (2014). "Scale Indicators of Social Exchange Relationships: A Comparison of Relative Content Validity", Journal of Applied Psychology, 99(4), ss.599-618.

Cropanzano, R., ve Mitchell, M. (2005). "Social Exchange Theory: An Interdisciplinary Review", Journal of Management, 31, ss.874-900.

Çavuşoğlu, S., Palamutçuoğlu ve B. T. (2017). "İş Tatmininin Sanal Kaytarma Üzerindeki Etkisi”, Mehmet Akif Ersoy Üniversitesi Sosyal Bilimler Enstitüsü Dergisi, Cilt 9, Say1 19, ss.430-444.

Çivilidağ, A. (2015). "Öğretim Elemanlarında Örgütsel Sinizm ve İșe Yabancılaşma Arasındaki İlişkide Yaşam Doyumunun Aracı Rolü”, "işş, Güç” Endüstri İlişkileri ve İnsan Kaynakları Dergisi, Cilt 17, Sayı 1, ss.259-286.

Eisenberger, R., Huntington, R., Hutchison, S. ve Sowa, D. (1986). "Perceived organizational support", Journal of Applied Psychology, 71, ss.500-507.

Eisenberger R, Cotterell N ve Marvel J. (1987). "Reciprocation ideology", Journal of Personality and Social Psychology, 53, ss.743-750 
Algılanan Sosyal Mübadele, İşe Yabancılaşma ve Sanal Kaytarma Davranışlarını Etkiler Mi? Mübadele İdeolojisinin Düzenleyici Rolü

Eisenberger, R., Armeli, S., Rexwinkel, B., Lynch, P. D. ve Rhoades, L. (2001). "Reciprocation of Perceived Organizational Support", Journal of Applied Psychology, 86(1), ss.42-51.

Glassman, J., Prosch, M. ve Shao, B. B. M. (2015). "To monitor or not to monitor: Effectiveness of a cyberloafing countermeasure", Information \& Management, 52, ss.170-182.

Gouldner, A. W. (1960). "The norm of reciprocity: A preliminary statement", American Sociological Review, 25, ss.161-178.

Göktepe, A. O. (2012). Zihni Temsillerin (Sosyal ve Ekonomik Takas Yaklaşımı) Çalışılan Kuruma Bağlanmaya (Cezbolma, Özdeşleşme ve Bağlllık) Etkisinde Örgütsel Destek Ve Dışsal Prestij Algılarının Rolü, Marmara Üniversitesi Sosyal Bilimler Enstitüsü İşletme Ana Bilim Dalı Yönetim ve Organizasyon Bilim Dalı, Doktora Tezi, İstanbul.

Greenfield, B.N.ve Davis, R.A. (2002) "Lost in Cyberspace: The Web@Work", Cyberpsychology and Behavior, 5(4), ss.347-353.

Hirschfeld, R. R. ve Field, H. S. (2000), "Work Centrality and Work Alienation: Distinct Aspects of a General Commitment to Work", Journal of Organizational Behavior, 21(7), ss.789-800.

Jiang, J. Y. ve Law, K. S. (2013). "Two parallel mechanisms of the relationship between justice perceptions and employees' citizenship behavior: A comparison of the organizational identification and social exchange perspective", European Journal of Work and Organizational Psychology, 22(4), ss.423-435.

Kanten, P. ve Ülker, F. (2014). "Yönetim Tarzının Üretkenlik Karşıtı İş Davranışlarına Etkisinde İşe Yabancılaşmanın Aracılık Rolü", Muğla Sıtkı Koçman Üniversitesi Sosyal Bilimler Enstitüsü Dergisi, Say1 32, ss.16-40.

Karagonlar, G., Öztürk, E. B. ve Özmen, Ö. N. T. (2015). "Çalışanın örgütle sosyal mübadele alg1sı ve işten ayrılma niyeti: İşe cezbolmanın ve özyeterliliğin rolü”, ODTÜ Gelişme Dergisi, Cilt 42, ss.411-433.

Karataş, A. ve Avcı, S. B. (2017). "Kamu kurumlarında Sanal Kaytarma Olgusunun Değerlendirilmesi”, Süleyman Demirel Üniversitesi İktisadi ve İdari Bilimler Fakültesi Dergisi, C.22, Kayfor15 Özel Sayıs1, ss.23212346.

Kim, T. Y., Aryee, S., Loi, R. ve Kim, S. P. (2013). "Person-organization fit and employee outcomes: test of a social exchange model", The International Journal of Human Resource Management, 24(19), ss.3719-3737

Ladd, D. ve Henry, R. A. (2000). "Helping Coworkers and Helping the Organization: The Role of Support Perceptions, Exchange Ideology, and Conscientiousness", Journal of Applied Social Psychology, 30(10), ss.2028-2049.

Liberman, B., Seidman, G., McKenna, K. Y. A., ve Buffardi, L. E. (2011). "Employee job attitudes and organizational characteristics as predictors of cyberloafing", Computers in Human Behavior, 27, ss.2192-2199 
Lim, V. K. G. (2002). "The IT way of loafing on the job: Cyberloafing, neutralizing and organizational justice", Journal of Organizational Behavior, 23, ss.675-694.

Lim, V. K. G. ve Teo, T. S. H. (2005). "Prevalence, Perceived Seriousness, Justification and Regulation of Cyberloafing in Singapore", Information \& Management, 42(8), ss.1081-1093.

Lim, V. K. G. ve Chen, D. J. Q. (2012). "Cyberloafing at the workplace: Gain or drain on work?”, Behaviour \& Information Technology, 31, ss.343-353.

Mendoza M. J. S. ve Lara, P. Z. M. (2007). "The impact of work alienation on organizational citizenship behavior in the Canary Islands", International Journal of Organizational Analysis, 15(1), ss.56-76.

Mercado, B. K., Giordano, C. ve Dilchert, S. (2017). "A meta-analytic investigation of cyberloafing”, Career Development International, 22(5), ss.546-564.

Meydan, C. H. Ve Şeşen, H. (2015). Yapısal Eşitlik Modellemesi: AMOS Uygulamaları., 2. Bask1, Detay Yayıncılık, Ankara.

Mottaz, C.J. (1981). "Some Determinants of Work Alienation", Sociological Quarterly, 22, ss.515-529.

Nair, N. ve Vohra, N. (2009). "Developing a New Measure of Work Alienation", Journal of Workplace Rights, 14, ss. 293-309.

Nair, N. ve Vohra, N. (2010). "An exploration of factors predicting work alienation of knowledge workers", Management Decision, 48(4), ss.600615.

Öcal, H. ve Barın, N. (2016). "Örgütlerde Otantik Liderlik Davranışının İşe Yabancılaşma ile İlişkisi: Bursa İli Dericilik Sektöründe Bir Araştırma", “İş, Güç” Endüstri İlişkileri ve İnsan Kaynakları Dergisi, 18(2), ss.63-94.

Örücü, E. ve Aksoy, M. (2018). "Sanal Kaytarma ve Beş Büyük Kişilik Özelliği Arasındaki İlişkiye Yönelik Bir Araştırma", Pamukkale Üniversitesi Sosyal Bilimler Enstitüsü Dergisi, Sayı 30, ss.265-282.

Özbek, M. F. (2011). “Örgüt İçerisindeki Güven ve İșe Yabancılaşma İlişkisinde Örgüte Uyum Sağlamanın Aracı Rolü”, Süleyman Demirel Üniversitesi Iktisadi ve İdari Fakültesi Dergisi, 16(1), ss.231-248.

Özdemir, H. Ö. (2017). Yöneticilerin Otantik liderlik Tarzlarının Çalışanların Sanal Kaytarma ve Sinizm Davranışları Üzerine Etkileri, Nevşehir Hacı Bektaş Veli Üniversitesi Sosyal Bilimler Enstitüsü İşletme Ana Bilim Dalı, Doktora Tezi, Nevşehir.

Pan, W., Sun, L. Y. ve Lam, L. W. (2017). "Employee-organization Exchange and employee creativity: a motivational perspective", The International Journal of Human Resource Management, 24(1), ss.1-23.

Podsakoff, P. M., Mackenzie, S. B., Lee, J. ve Podsakoff, N. P. (2003). "Common Method Biases in Behavioral Research: A Critical Review of the Literature 
Algılanan Sosyal Mübadele, İşe Yabancılaşma ve Sanal Kaytarma Davranışlarını Etkiler Mi? Mübadele İdeolojisinin Düzenleyici Rolü

and Recommended Remedies", Journal of Applied Psychology, 88(5), ss.879-903.

Podsakoff, P. M., Mackenzie, S. B. ve Podsakoff, N. P. (2012). "Sources of Method Bias in social Science Research and Recommendations on How to Control It", Annual Review of Psychology, 63, ss.539-569

Redmond, E. (2013). "Competency Models At Work: The Value of Perceived Relevance and Fair Rewards for Employee Outcomes", Human Resource Management, 52(3), ss.771-792.

Robinson, S. L. ve Bennett, R. J. (1995). "A typology of deviant workplace behavior: A multidimensional scaling study", Academy of Management Journal, 38(2), ss.555-572.

Rupp, D. E. (2002). "The mediating effects of social exchange relationships in predicting workplace outcomes from multifoci organizational justice", Organizational Behavior and Human Decision Process, 89, ss..925-946.

Sarros, J. C., Tanewski, G. A., Winter, R. P., Santora, J. C. ve Densten, I. L. (2002). "Work Alienation and Organizational Leadership", British Journal of Management, 13, ss.285-304.

Seeman, M. (1959). "On the Personal Consequence of Alienation in Work", American Sociological Review, 24, ss.783-791.

Shantz, A., Alfes, K. ve Truss, C. (2014). "Alienation from work: Marxist ideologies and twenty-first-century practice", The International Journal of Human Resource Management, 25(18), ss.2529-2550.

Shantz, A., Alfes, K., Bialey, C. ve Soane, E. (2015). "Drivers and Outcomes of Work Alienation: Reviving a Concept", Journal of Management Inquiry, 24(4), ss.382-393.

Shepard, J. M. 1970. "Functional Specialization: Alienation, and Job Satisfaction", Industrial and Labor Relations Review 23 (2), ss.207-219.

Shin J., Taylor, M. S. ve Seo, M. G. (2012). "Resources for Change: The Relationships of Organizational Inducements and Psychological Resilience to Employees' Attitudes and Behaviors Toward Organizational Change", Academy of Management Journal, 55(3), ss.727-748.

Shore, L.M., Tetrick, L.E., Lynch, P. ve Barksdale, K. (2006), "Social and Economic Exchange: Construct Development and Validation", Journal of Applied Social Psychology, 36, ss.837-867.

Shore, L. M., Bommer, W. H., Rao, A. N. ve Seo, J. (2009) "Social and economic exchange in the employee-organization relationship: the moderating role of reciprocation wariness", Journal of Managerial Psychology, 24(8), ss.701-721.

Song, L. J., Tsui, A. S. ve Law, K. S. (2009). "Unpacking Employee Responses to Organizational Exchange Mechanisms: The Role of Social and Economic Exchange Perceptions", Journal of Management, 35(1), ss.5693. 
Tanrıverdi, H. ve Kahraman, O. C. (2016). "5 Yıldızlı Otel İşletmelerinde LiderÜye Etkileşimi ve İşe Yabancılaşma İlişkisi: Marmaris ve İstanbul Destinasyonlarında Bir Araştırma", Dokuz Eylül Üniversitesi Sosyal Bilimler Enstitüsü Dergisi, 18(3), ss.463-493.

Turgut, T. ve Kalafatoğlu, Y. (2016). "İşe Yabancılaşma ve Örgütsel Adalet", "İş, Güç” Endüstri İlişkileri ve İnsan Kaynakları Dergisi, 18(1), ss.27-46.

Tutar, H. (2010). "İ̧̧ören Yabancılaşması ve Örgütsel Sağlık İlişkisi: Bankacılık Sektöründe Bir Uygulama", Ankara Üniversitesi Siyasal Bilgiler Fakültesi Dergisi, 65/1, ss.175-204.

Witt, L. A. (1991). "Exchange ideology as a moderator of job attitudesorganizational citizenship behaviors relationships", Journal of Applied Social Psychology, 21, ss.1490-1501.

Witt, L. A., Kacmar, K. M. ve Andrews, M. C. (2001). "The interactive effects of procedural justice and exchange ideology on supervisor-rated commitment", Journal of Organizational Behavior, 22, ss.505-515.

Yıldırım, F. (2018). "Tükenmişlik Düzeyinin Sanal Kaytarma Davranışına Etkisinde İş Doyumunun Aracılık Rolü”, Gazi Üniversitesi Sosyal Bilimler Dergisi, 5(13), ss.302-313.

Yıldız, B. Ve Yıldız, H. (2015). "İs Yaşamındaki Sanal Kaytarma Davranışlarının Hukuki Yönden İncelenmesi”, Yönetim ve Ekonomi Araştırmaları Dergisi, 13(3), 1-17. 